
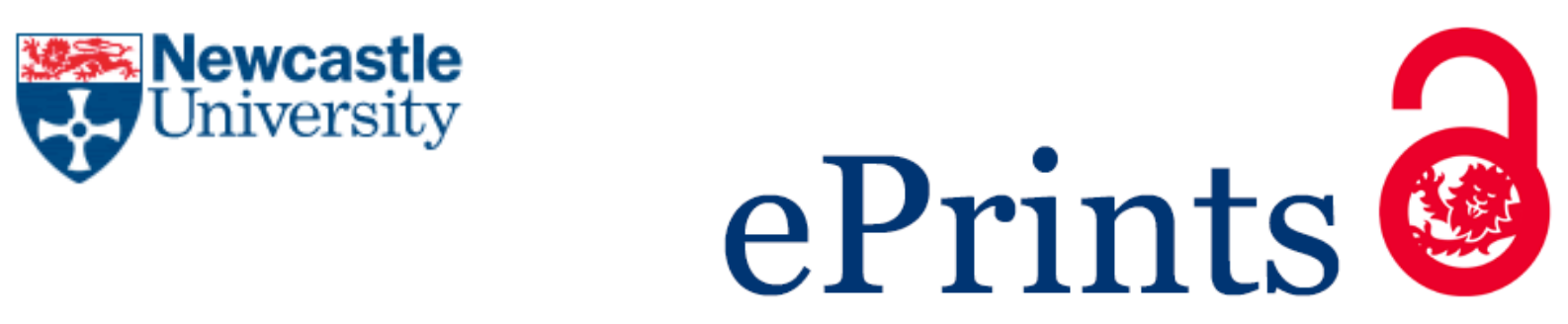

\author{
Liu LYJ, Hussain S, Zuo LY, Wang Y. \\ Journal Rankings, Collaborative Research and Publication Strategies: \\ Evidence from China.
}

Accounting Education 2015, 24(3), 233-255.

\title{
Copyright:
}

This is an Accepted Manuscript of an article published by Taylor \& Francis in Accouting Education on 30/06/2015, available online: http://dx.doi.org/10.1080/09639284.2015.1037776

Date deposited:

$27 / 04 / 2015$

Embargo release date:

30 December 2016

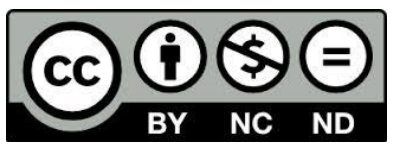

This work is licensed under a

Creative Commons Attribution-NonCommercial-NoDerivatives 4.0 International licence 


\title{
Journal Rankings, Collaborative Research and Publication Strategies: Evidence from China
}

\begin{abstract}
The primary focus of our paper is on the potential for in-house journal ranking lists to create friction between international collaborating researchers due to differences in how particular journals are rated on different lists. Using a questionnaire distributed to Chinese accounting researchers we identify a number of potential friction points between Chinese and UK researchers. We find that almost all of our Chinese respondents use their own school's in-house ranking list as the primary or exclusive reference point for assessing journal quality, and $73 \%$ of respondents acknowledge that this has caused problems when working with scholars from other universities because of differences in how their institutions rank journals.
\end{abstract}

Key words: Journal ranking lists; Publication strategies; Collaborative research; China; Questionnaire. 


\section{Journal Rankings, Collaborative Research and Publication Strategies: Evidence from China}

\section{Introduction}

\subsection{Overview}

In this paper we question whether the increasing use of in-house journal ranking lists across the international business school sector is inhibiting international collaborative research in accounting due to differences in how journals are ranked on different lists. Using a questionnaire distributed to Chinese accounting researchers we identify a number of potential friction points between Chinese and UK researchers. ${ }^{1}$

The issue has particular relevance to the accounting education community because despite calls for accounting education studies which cross national boundaries (Apostolou et al., 2010), and the geographical diversity of editorial board members and article contributors to this journal (Jackling et al., 2013), transnational research work in accounting education is still 'rare', relative to other areas (Marriott et al., 2014, p.272).

Our focus is on accounting academics in China, a country with which many North American and European business schools are seeking to forge research links. ${ }^{2}$ We find that almost all of our Chinese respondents use their own school's in-house ranking list as the primary or exclusive reference point for assessing journal quality, and $73 \%$ of respondents acknowledge that this has caused problems when working

\footnotetext{
${ }^{1}$ We believe these problems could apply to any scenario in which the respective universities of collaborating researchers make exclusive use of different ranking lists. It is even possible that within the same country the exclusive use of different ranking lists by different institutions could create similar problems (Malsch and Tessier, 2015).

2 This reflects the fact that Asian business schools have been moving from a predominantly knowledge-disseminating role to one of knowledge-creation ( $\mathrm{Au}$, 2007)
} 
with scholars from other universities because of differences in how their institutions rank journals.

Beyond our primary focus on potential frictions in transnational collaborative research, our survey also reveals trends within our respondents' publication strategies. The clear majority of respondents acknowledge that the use of in-house ranking lists pressures them to avoid more appropriate but specialised niche journals (72\%); discourages them from sending papers to newly launched journals (81\%), and discourages engagement with professionally-orientated journals (57\%). Several of these findings link with concerns that have been raised by academics in the wider international community (Moya et al., 2014; Marriott et al., 2014).

\subsection{Contribution}

Prior studies have investigated the incentives for academics to engage in collaborative research. These include both functional and social dimensions (e.g. Laband and Tollison, 2000; Melin, 2000; Zutshi et al., 2012). The problems resulting from collaborative work have also been documented and investigated (e.g. Katz and Martin, 1997; Grando and Bernhard, 2003; Melin, 2000; Urbancic, 2009) but little has been published on the potential frictions between collaborating researchers deriving from the use of in-house journal ranking lists. We believe that this gap in the literature needs to be addressed as the use of in-house ranking lists continues to spread across the international business school sector.

The paper is organized in the following way. Section 2 gives some background on issues connected with collaborative research and develops a set of research questions around those areas that are most likely to be causes of friction between collaborating researchers. Section 3 presents the results for our main focus - the 
potential impact of ranking lists on collaborative research. Section 4 presents evidence on a number of related but different questions regarding the impact of lists on publication strategies (e.g. professional journals, specialist vs. mainstream journals). Section 5 provides some comments on the list construction process and suggests possible avenues for future research. The conclusion ends the paper.

\section{International Collaboration in Accounting Research}

\subsection{Background to this study}

Our paper has its genesis in a discussion between a colleague at one of the UK's Russell Group universities and their co-researcher, who was based in a major '211' Chinese university. ${ }^{3}$ Having completed a significant piece of collaborative research, both academics were under pressure from their respective research deans to publish their findings in the best journal for their particular subject specialism (management accounting).

The UK academic was strongly advised to follow the journal rankings of the Association of Business Schools (ABS) Academic Journal Quality Guide, which meant aiming for Management Accounting Research $(M A R) .{ }^{4}$ However, their Chinese colleague's research manager urged the use of their school's own internal listing, which identified the US-based Journal of Management Accounting Research $(J M A R)$ as the superior outlet. In both cases the other journal was rated in a lower quality category. The consequences for publishing articles in lower quality categories, for both researchers, included potential reductions in research time and diminished

\footnotetext{
${ }^{3}$ The Russell Group is a self-selecting group consisting of 24 of the UK's leading research universities. China's '211 project' listed universities are the 118 leading research universities as identified by China's Ministry of Education.

${ }^{4}$ At time of writing, the successor to the ABS guide has just been launched. However, given the time of our survey (2011), we will make reference to the ABS guide thought this paper rather than its successor.
} 
promotion prospects. Given the significant negative consequences for career development for faculty who publish in the 'wrong' journals, such pressures could lead some academics to reappraise the benefits of collaborative international research. The example above is not a singularity and similar problems can even afflict the same individual if they move from one region to another, as noted by Malsch and Tessier (2015, p.87):

When I moved to England in 2003 to do my $\mathrm{PhD}$, I had already been hired by my school [in Canada] ... There, I was exposed to well-regarded academic journals such as Accounting, Organizations \& Society (AOS), Management Accounting Research (MAR) and Accounting, Auditing \& Accountability Journal (AAAJ) and more importantly to qualitative methods ... Upon my return to Montreal, three years later, I noticed that most of the journals I knew and considered to be at the top of the field were not part of my school's ranking system ... Of course, I could have just changed my research field for one that was better represented by the school's ranking system. However, I did not want to renounce a fascinating research field that challenged me intellectually just to get value units.

This quote demonstrates that ranking-based pressures for academics to skew their work towards different accounting journals, and even different research areas, it is an international phenomenon.

\subsection{Why collaborative research matters}


The importance of collaborative research work for maintaining an active and relevant business school research agenda appears to be recognised by a number of influential external bodies. In addition, from a purely academic perspective there is also considerable evidence on the potential benefits of collaborative research to individual scholars.

There is strong encouragement from school-accreditation bodies both for international research activity, and research that is user-relevant. Having an international perspective in business research is stated as an important requirement by the US-based accreditation body, the Association to Advance Collegiate Schools of Business (AACSB):

\begin{abstract}
AACSB is committed to its role as the world's leader in the advancement of management education. This global mindset is an integral and pervasive element ... and is reflected in all organizational functions and actions. ${ }^{5}$
\end{abstract}

The European Foundation for Management Development (EFMD) is Europe's largest network association in the field of management development and is linked with the European Quality Improvement System (EQUIS). They state that:

Institutions that are accredited by EQUIS must demonstrate not only high general quality in all dimensions of their activities, but also a high degree of internationalisation. ... EQUIS looks for a balance between high academic

\footnotetext{
${ }^{5} \mathrm{http}: / /$ www.aacsb.edu/
} 
quality and the professional relevance provided by close interaction with the corporate world. ${ }^{6}$

A third accrediting body, which together with AACSB and EQUIS constitutes the third arm of 'triple accredited' status, is the UK based Association of MBAs (AMBA). In their accreditation documents they state that:

Research quality should be of a high standard in all areas of activity and show some evidence of an international dimension ... The institution should be able to demonstrate that there are effective mechanisms by which results from research, consultancy and contact with the organisational corporate world are regularly incorporated into MBA provision. ${ }^{7}$

From the viewpoint of individual academics too there are also benefits to be gained from collaboration. One obvious benefit is the ability to address particularly complex problems from multiple perspectives, something that may be easier for a team of individuals than for a single researcher (Laband and Tollison, 2000). This is perhaps even more important when conducting international research projects where no single academic has full knowledge of the business practices within the other researchers' countries.

Collaborative research also allows the development of networks with earlycareer researchers in other countries (Zutshi et al., 2012). The development of such networks can be beneficial for both individual researchers and their respective schools. Of course, collaborative work can also allow for a more efficient use of

\footnotetext{
${ }^{6} \mathrm{https}: / /$ www.efmd.org/index.php/accreditation-main/equis

${ }^{7}$ http://www.mbaworld.com/
} 
individuals' time and resources than would be the case if the project was undertaken by a single researcher (Melin, 2000). In addition to these practical/functional perspectives on collaboration, individual researchers sometimes seek collaboration for social reasons too. Melin's (2000) survey of 195 researchers reports that around a quarter of respondents list 'social reasons' among their reasons for undertaking collaborative work.

However, the literature on collaborative research also identifies potential sources of friction between collaborative researchers (e.g. Hafernik et al.,1997; Fleischman and Schuele, 2009). These can range from issues such as the order in which authors' names appear on a paper and/or the inclusion of names of individuals who have not contributed significantly to the work (Grando and Bernhard, 2003; Melin, 2000; Urbancic, 2009), to fundamental disagreements about how the results should be interpreted (Katz and Martin, 1997).

We are not presently aware of any prior studies that have addressed the issue of frictions within collaborative research in relation to the use of in-house journal ranking lists and we believe that this gap in the literature needs to be addressed.

\subsection{Our research questions}

There is already a significant body of work on the ranking of accounting journals, although not in relation to our particular research focus (e.g. Beattie and Goodacre, 2006, 2012; Chan et al., 2009; Hussain, 2010, 2011; Sangster, 2011; Hoepner and Unerman, 2012; Glover et al., 2012; Fogarty and Jonas, 2013; Dunbar and Weber, 2014; Holderness et al., 2014). The increasing obsession with metricizing and ranking research outputs both for individual faculty and universities is now well documented across a range of countries including the US (Adler and Harzing, 2009; 
Giacalone, 2009; Hitt and Greer, 2012; Collet and Vives, 2013; Ashford, 2013; Currie and Pandher, 2013), Canada (Malsch and Tessier, 2015), South Africa (Nkomo, 2009), Australia (Moosa, 2011) and the UK (Tourish, 2011; Taylor, 2011; Willmott, 2011; Nedeva et al., 2012; Hussain, 2015). Indeed, the topic has been recognised as important enough for leading business education journals to devote large portions of dedicated issues to the subject (e.g. Academy of Management Learning and Education vol. 8:1, 2009; Accounting Education: an international journal vols. 20:6, 2011 and $21: 1,2012)$

Because journal rankings are not the same across all lists there is scope for considerable friction to be created when working with colleagues from different regions and institutions. Given the origins of our paper, our focus is on Chinese scholars and their perspectives on research within the subject area of accounting. Respondents' views are obtained via a questionnaire and focus on several likely sources of potential friction with potential collaborators. These sources of friction are as follows: (i) identification of top-tier journals; (ii) perceptions of specialist/niche journals; (iii) local/regional Asian academic journals.

It should be noted that in addition to examining these factors we also take the opportunity to ask several questions on a different but related area - how ranking lists are impacting publication strategies by Chinese academics. Do ranking lists encourage a move away from professional journals? Evidence of such pressure elsewhere has been documented by Moya et al. $(2014$, p.2):

“[In Spain,] publishing papers in prestigious academic journals has become an important criterion for promotion and tenure, especially since the passing of the 2001 Spanish University Act (Ley Orga'nica de Universidades). Unlike in 
the past, when papers published in professional journals were acceptable, the new regulation only considers papers published in indexed academic journals - a change that has completely transformed the Spanish accounting arena.”

There is also the question of whether ranking lists lead to pressure to publish in mainstream journals when more specialised/niche journals may be considered more appropriate from the viewpoint of communicating with likeminded researchers (see Marriott et al., 2014, p.277). Our results are presented separately for those questions relating specifically to the sources and impact of ranking lists on collaborative research, and for those questions relating more broadly to how ranking lists have impacted publication strategies.

We construct a questionnaire to be distributed to Chinese accounting academics, having first investigated likely areas of disagreement with potential overseas collaborators. These areas of disagreement are identified by examining the ratings of journals on a range of different lists. In framing the questions we began by examining accounting journals' ratings on a number of Chinese universities' journal quality lists available at May 2011. The aim was to identify any notable trends that could form the basis of a questionnaire. One of the lists we reviewed was that from the Shanghai University of Finance and Economics itself. ${ }^{8}$ However, we were also given access to detailed ratings from a major Hong Kong-based university on condition that they were not identified in any research project. This anonymous university has a research active business school as evidenced by its appearance in the top-10 most prolific Asia Pacific business schools for publications in seven top management journals during 1990-2006 (see Mudambi et al., 2008, Table 3).

\footnotetext{
${ }^{8}$ We used the 2009 version is available at: http://iar.shufe.edu.cn/structure/gdyjy/kygl_con_30863_1.htm
} 
Given that this study is motivated by problems deriving from China-UK research, the UK's Association of Business Schools (ABS) Academic Journal Quality Guide is frequently referenced here as a comparator ranking source: we use ratings from both the 2009 and 2010 editions $^{9}$. While the use of the ABS guide is not mandatory it has fast taken root as the primary source of ratings for business research journals. The ABS guide attempts to standardise research quality ratings across all business disciplines as nationally recognised (' 1 '), internationally recognised ('2'), internationally excellent ('3') and top international journals ('4'). The construction and properties of this list have been discussed in a number of papers (e.g. Hussain, 2010, 2015; Willmott, 2011; Taylor, 2011; Mingers and Willmott, 2013). Chinese universities' lists also tend to use a four-tier approach to quality classes. The ‘anonymous' Hong Kong-based Chinese university list uses A, B+, B and B-, in descending order of quality, while the list published by the Shanghai University of Finance and Economics identifies 'Top', 'First', 'Second' and 'Third' tiers of journal quality. ${ }^{10}$ There is presently no Asian Pacific equivalent to the UK's ABS listing.

Inspecting these lists helps identify the following areas of potential conflict for academics working jointly with Chinese counterparts:

\section{- The identification of 'top international' journals}

Top-tier journals are the most sought after publications in any institution, being perceived as evidence of the highest quality of academic work. While both the ABS and Chinese lists include the 'big 3' US journals (Accounting Review, Journal of Accounting and Economics, Journal of Accounting Research) in their top tiers, the three lists give different rankings to the empirically-driven journal Contemporary

\footnotetext{
${ }^{9}$ The 2009 and 2010 editions have some variations in terms of journal coverage, especially for Asian based journals, so we use both lists here.

${ }^{10} \mathrm{~A}$ more recent version of this list uses $\mathrm{A}, \mathrm{B}, \mathrm{C}+$ and $\mathrm{C}$ as the category headings.
} 
Accounting Research $(C A R)$ and the more sociologically focused journal Accounting Organizations and Society (AOS). CAR is in a higher class on both Chinese lists but $A O S$ is the superior journal on the UK's ABS list. ${ }^{11}$ Given the premium in terms of salary and promotion that follow from hitting top-tier journals, these variations are likely to be a non-trivial matter.

- The ranking of specialist/niche journals

Within most major business disciplines there will usually be a range of sub-strands of research that have become well developed in their own right, whilst still representing a specialisation of the broader discipline. Journals for these specialisms are often prone to significant ranking variations across different lists. For these specialist areas, lists will often single-out one journal as being higher ranked than the others so researchers have only one opportunity at gaining a 'good' publication. Whilst these are rarely top-tier journals, variations between second and third tier rankings can be very significant for faculty career development, as explained by Sangster (2011). One example of a well-developed theme within accounting is management accounting. The two best known dedicated journals are the UK based Management Accounting Research $(M A R)$ and the American Accounting Association affiliated Journal of Management Accounting Research (JMAR). The ABS list places MAR in a higher class than $J M A R$, while both Chinese listings reverse this ordering. The questionnaire will help provide a direct insight into the perceptions of Chinese respondents.

- The ranking of journals dedicated to the Asia Pacific region

Asian focused journals like Asia Pacific Journal of Accounting and Economics and Journal of Contemporary Accounting and Economics are ranked alongside well

\footnotetext{
${ }^{11}$ Interestingly, the relatively lower rating for $A O S$ has been recorded in other regions too such as North America (Malsch and Tessier, 2015, Table 1) despite the journal appearing on the elite Financial Times list.
} 
established European journals like $M A R$ on the anonymous Chinese university's list but are not even listed on the 2010 edition of the UK's ABS guide. How well are these regional journals viewed by Chinese academics? Respectable ratings for these journals could again indicate cases where friction could arise between Chinese and UK collaborators.

Of course, while examining different guides may provide a rationale for suggesting that ranking lists impact on collaborative work and publication strategies, we need to address these issues directly. In the fourth section of the questionnaire (Q4.1- 4.4) we ask explicit questions on these issues. However, the questionnaire opens with a range of more general questions regarding respondents' personal backgrounds, research areas and their familiarity with the UK's ABS Academic Journal Quality Guide. These questions help provide a broader context within which the other responses can be set. The questionnaire ends with a free-text section.

\section{Ranking Lists and Collaborative Accounting Research: Results}

\subsection{Introductory questions}

Our survey consists of a questionnaire (Appendix 1) distributed to participants of an international symposium on accounting held at the Shanghai University of Finance and Economics, between $24^{\text {th }}$ and $25^{\text {th }}$ June 2011 . This university has a long established record of research excellence in accounting research and its conferences attract a wide range of Chinese and international researchers. A total of 54 completed questionnaires were returned out of a total of 200 questionnaires given out. ${ }^{12}$ An English language version of the questionnaire is included in Appendix 1 although

\footnotetext{
12 These were distributed by one of this paper's authors to attendees following the first day's registration and during the lunch break on a first-come-first-served basis.
} 
Chinese versions were available to the respondents. The questionnaire begins with a series of general questions.

We acknowledge that our study is primarily descriptive in nature. While we report our findings in a tabular format, these are intended to be indicative rather than to be employed in formal statistical testing. Responses to our personal background questions (see Q1.1 to 1.3 in the questionnaire) are summarised in Table 1.

Table 1 here

These responses show that our faculty are drawn in an approximate 60:40 ratio between the research-intensive ' 211 ' universities and non-' 211 ' universities. Just under a fifth are from the '985 group' of 39 elite universities, which are a subset of the ' 211 ' grouping. ${ }^{13}$ However, all respondents classify themselves as 'research active' regardless of institution. Around three fifths of respondents are at the assistant professor/lecturer level, with three tenths at the associate professor/senior lecturer level and the remaining respondents at the full professor/chair level.

It should be noted here that the terms 'lecturer' and 'senior lecturer' were only included in case a respondent came from a university which used the UK's terminology for faculty status. In the US these terms usually denote teaching-only faculty, while research-active faculty are referred to as assistant or associate professor. All respondents to our questionnaire are research active faculty.

We ask respondents to identify their research area (Q1.5): up to three research areas can be chosen from a list of twelve. The results are shown in Table 2.

\footnotetext{
${ }^{13}$ The list of 39 universities was finalised by the Chinese government in 2011. This subset of 211 universities receives special additional funding.
} 
Table 2 here

Table 3 here

The most striking feature here is the relative popularity of 'Accounting and Capital Markets' possibly reflecting the growing US influence on Chinese academic perceptions but also the fact that this is a major focus for the journals that are most highly rated on Chinese lists. While all respondents at the professorial level included 'Management Accounting' among their top three interests, little more than one quarter of assistant professors and two fifths of associate professors expressed a strong interest in this topic. By contrast, the reverse was true for the 'Accounting and Capital Markets' where around three quarters of assistant professors and associate professors identify this topic as a major interest but only two fifths of the professorial respondents concurring. This could reflect the growing influence of journal ranking lists over recent years since no management accounting journals are classed as toptier. Senior faculty members, however, are likely to have developed their research interests some time ago before the heavy-handed use of journal lists became so widespread. Of course, it is also the case that the past few decades have seen a major increase in the scope and availability of large financial databases which particularly encourage quantitative, US-style empirical work. We do not examine the causes of these variations in research areas.

Respondents were also asked to indicate the importance of research to their career development (Q2.2) and the relative difficulty of publishing in what would be counted as 'high quality' journals in accounting (Q2.3 and 2.4). Table 3 shows that the vast majority of respondents considered research to be the single most important 
factor in determining their career development. None thought teaching was more important (untabulated). There was widespread belief that hitting what would be viewed as high quality journals was more difficult for accounting academics than for

researchers in general management areas. ${ }^{14}$ Around three quarters of respondents also thought that obtaining high quality outputs in management accounting was more difficult than in other areas of accounting. Interestingly, this proportion remains high (65\%, untabulated) even when researchers with an interest in management accounting are excluded. Since journals such as $M A R$ and $J M A R$ do not appear in the top tier of journal lists, this finding is perhaps merely a reflection of this problem.

The next section refers to those questions relating directly to our primary research question: Do in-house lists have the potential to cause frictions between collaborating researchers?

\subsection{Ranking list usage in China and perceptions of journal quality}

Here we look at journal quality ranking lists and how the exclusive use of particular lists at different universities may cause frictions when conducting collaborative international research. Table 4 presents evidence on which lists are used.

Table 4 here

The single most overwhelming finding is that Chinese universities focus almost exclusively on their own in-house ranking lists to assess the quality of accounting journals. This mirrors the current situation across most North American institutions. It also mirrors the situation that existed in UK business schools prior to the emergence

\footnotetext{
${ }^{14}$ This view reflects opinions expressed by the Chair of the British Accounting Association/British Accounting and Finance Association (Hellier, 2011).
} 
of the ABS guide. Indeed, some individual school ratings were included in early versions of the ABS guide (see Kelly, et al., 2009; Hussain, 2010, Table 1). The ABS guide is mentioned by respondents but only as a secondary listing, and by less than one fifth of respondents (18.5\%). Interestingly, knowledge of the ABS guide increases with seniority, as can be seen in Table 5 .

\section{Table 5 here}

While this pattern may be expected, given the greater experience of senior faculty, it still shows that only a minority of senior faculty have knowledge of the ABS guide and its ratings. Other international ranking guides (Q2.1) have virtually no profile among the respondents. This is likely to entrench the power of their own school listings and exacerbate potential conflicts with non-Chinese research colleagues.

Following on from these more general questions, we start examining potential areas of friction between international collaborators. One such area is the perceived quality of particular journals. Respondents are asked to suggest ratings for a list of journals (Q3.2). We deliberately avoid using an exhaustive list of all accounting journals: this would likely deter completion of the questionnaire in a meaningful manner. We believe that by identifying a smaller sample of potentially problematic journals, we will solicit more thoughtful and considered responses. Responses are summarised in Table $6 .^{15}$

Table 6 here

\footnotetext{
15 The rankings for all journals in our questionnaire are reported in Appendix 2.
} 
Firstly, with regard to 'top international' journals, both $C A R$ and $A O S$ are the highest rated within our sample of journals and have near identical average scores. However, while UK business school deans would have much preferred their faculty to obtain publications in $A O S$ at the time of our survey, due to it being rated in a higher class on the ABS list, the evidence of our survey, together with the actual ratings given in our Chinese lists, indicate that Chinese academics would consider $C A R$ to be at least equivalent to $A O S$ and possibly better.

The next issue relates to specialist/niche journals, in this case the relative rankings of the two leading journals for management accounting, MAR and JMAR. While both perform well on this questionnaire, JMAR clearly outscores MAR among Chinese academics, performing better across each of the three academic grades and consistent with the ratings on the two Chinese lists we have referenced. Again, this discrepancy would cause problems for UK academics working on joint projects with Chinese colleagues. Within the UK education system where the ABS guide reigns, a second-tier journal like $M A R$ would be viewed much more favourably by a school dean than a third-tier journal like JMAR. Indeed, within the UK, the distinction between these two categories is often pivotal in determining research time, and also for major promotion decisions. For example, Beattie and Goodacre (2012, p.221) list the five most frequently appearing journals in the publication records of faculty promoted to Professor/Chair in the UK, all of which are first or second tier journals on the ABS list. The damaging personal consequences for some UK faculty of hitting only third-tier journals are also a matter of published record (Sangster, 2011) and apply to all business disciplines, not just accounting (Parker, 2014, p.285).

Finally, we turn to the geographical dimension to see how Asia-Pacific focused journals are viewed by Chinese academics. The omission of these journals 
from the 2010 ABS list (Harvey et al., 2010) would mean that UK faculty would be warned against publishing in any of these outlets. These are all viewed much more positively by our sample of Chinese academics. An obvious example is the Journal of Contemporary Accounting and Economics which ranks closely behind MAR in our survey and is similarly rated to $M A R$ in the anonymous Chinese university's list, but does not even appear on the ABS list. In the UK, business school researchers are normally encouraged to avoid unlisted journals.

The results presented above provide an illustration of how journal ratings could be a potential source of friction between researchers who collaborate across geographical regions. However, this friction is being inferred rather than stated explicitly so in the final set of questions we ask explicitly whether the use of ranking lists at their institution has caused problems when working with scholars from other universities because of differences in how their institutions rank journals (see Q4.2).

\section{Table 7 here}

The summary of the responses to this question are presented in Table 7 and are similar across all three grades of faculty - around three quarters answer in the affirmative. If anything, this figure is likely to be conservative given that some of the respondents may not have engaged yet in international work. ${ }^{16}$

In the next section we discuss a number of issues related publication strategies and the use of journal ranking lists within Chinese universities but not directly related to our focus on collaborative research impact.

\footnotetext{
${ }^{16}$ We do not have data on this characteristic.
} 


\section{Ranking Lists and Publication Strategies: Results}

\subsection{Specialist vs. mainstream journals}

The final group of questions on our questionnaire (Q4.1, 4.3 and 4.4) explicitly target the issue of how the existence of journal ranking lists impacts on respondents' publication strategies. The results are summarised in Table 7. The avoidance of specialist/niche journals is visible in these data, although it appears to become greater as the faculty grade increases. It is well known that more specialised journals, together with multidisciplinary journals, have tended to lose out in the ratings game relative to mainstream journals (e.g. Rentz, 2009; Hall, 2010; Tourish, 2011; Rafols et al., 2012). This issue is particularly relevant to areas such as accounting education:

While the outlets ... [list of mainstream accounting journals]... would probably not be considered obvious first choices for most work in this area ...The diaspora of education work may suggest that authors are currently being directed towards publishing in journals that are viewed as highly ranked in their home nations, an objective that might force them outside the welcoming arms of the specialty [i.e. accounting education] journals. (Marriott et al., 2014, p.277)

Our results are consistent with the concerns raised by Marriott et al. (2014). Attitudes to professional and newly launched journals are discussed next.

\subsection{Professional and Newly Launched Journals}


Section 5 of our questionnaire allowed for a free text entry although only a minority of respondents used this option. Among the free text comments, explicit reference was made to how newly-launched journals were treated on journal ranking lists:

\begin{abstract}
For those newly established journals, there needs to be more recognition of publications. (Associate professor at a non-'211' university)
\end{abstract}

This quote referring to newly launched journals supports one of our findings, namely the avoidance of newly launched journals by four fifths of the respondents, due to these journals' likely omission from journal ranking lists. The existence of journal lists has also had a negative impact on professional publications (Table 7). More than half of respondents (57\%) say that ranking lists have a negative effect on their publication strategies vis-à-vis professional journals. These results mirror those reported by Moya et al., (2014) in Spain when the government forced universities to focus on indexed academic journals only.

\title{
4.3. Accounting Education
}

Our paper is concerned with accounting research in general, rather than focusing solely on accounting education research, and our results do not provide any insight into whether collaborative research in accounting education is more or less impacted by ranking lists than any other accounting topic. However, a number of surveys of accounting education research have revealed that international collaboration has been relatively rare over the past few decades. While a majority of accounting education papers are joint-authored (Urbancic, 2009) there is little evidence for the emergence of the larger research teams which are more common in mainstream accounting 
journals (Marriott et al. 2014). Although there have been calls for accounting education studies which cross national boundaries (see Apostolou et al., 2010), evidence presented by Marriott et al. (2014, p.272) illustrates 'how rare it is for [accounting education] academics from different nations to collaborate in this field.'

Part of the explanation for this may be that in accounting education the opportunities for collaborative research with academics in countries like China are very limited. We find that only $5.6 \%$ of our respondents include accounting education among their top-3 research areas. This relatively low figure is entirely consistent with the influence of ranking lists. Among assistant professors only $3.1 \%$ mention accounting education as a major research interest while among associate professors this figure is almost four times greater $(11.8 \%)$. This may indicate that accounting education was more favourably regarded in the past, when the associate professors were developing their research careers, and has subsequently been badly hit by the increasing focus on ranking lists.

This suggestion is not merely idle speculation - it can be linked directly with documented evidence on how accounting education journals have been ranked over recent decades. In the UK, for example, prior to the emergence of the ABS list in 2007 journals such as Accounting Education: an international journal and the Journal of Accounting Education appeared in the top-tier of some major schools' in-house ranking lists (see Hussain, 2012, Table 2). In addition, Beattie and Goodacre (2012, p.221), who investigate the publication profiles of UK accounting and finance faculty promoted to chair/professor during 1992-2007, identify Accounting Education: an international journal as being within the top-6 journals most frequently appearing within the CVs of professorial appointees. Even the prototype for the ABS guide, often referred to as the 'Bristol list' (Harvey and Morris, 2004), gave Accounting 
Education: an international journal and the Journal of Accounting Education the equivalent of a ' 3 ' rating. Yet within a short space of time after the appearance of the first edition of the ABS list in 2007, UK faculty were being pressurised to move away from accounting education journals, all of which were now rated '2' (see Sangster, 2011). Perhaps these trends are reflected in the research interests of Chinese faculty and doctoral students, especially those with close ties to the UK. We cannot test this hypothesis with our data but it would be an interesting avenue for future research.

Next follows several additional issues that flow from our paper. These relate to comments in the free-text portion of the questionnaire and to avenues for future research.

\section{Additional Issues}

\subsection{Comments on the List Construction Process in China}

As mentioned above, our questionnaire allowed for a free text entry although only a minority of respondents used this option. There was explicit recognition of the impact that journal ranking lists:

$$
\begin{aligned}
& \text { Every university has its own listing...the listing has a significant impact on } \\
& \text { academics and PhDs. (Assistant professor at a '211' university) }
\end{aligned}
$$

However, there were often questions concerning the objectivity of their own school's rankings: 


\begin{abstract}
A lot of Chinese journals' rankings are mostly due to negotiations between interested parties, not based on objective appraisal. (Assistant professor at a '211' university)
\end{abstract}

When deciding on the rankings, there are some biases reflecting personal preferences. (Associate professor at a '211' university)

The internal 'politics' that underlie the journal ranking process is a significant issue within any school - who's opinions are considered, how are these opinions weighted, etc. While some evidence is emerging on this (e.g. Malsch and Tessier, 2015) more evidence is needed on the politics of the ranking process, particularly within emerging economic regions. Rather than merely being representative of each school's perceptions of quality it may be that across many schools these lists are driven by small, powerful cliques pushing their own research agendas.

\title{
5.2. Future Research
}

Obvious avenues for future research include the use of questionnaires and interviews within international business schools to assess:

- The value that Asia Pacific schools place on regional problem solving research that may be highly relevant to local business users but which may be limited in its opportunities to generate papers in leading North American or European journals;

- The value that Western schools place on collaborative research work with colleagues in Asia Pacific institutions, both in terms of producing current research outputs and with regard to developing stronger links with this rapidly developing region. 
These two issues would help to gain a school-level perspective on this issue.

Additional analyses in regard to examining the issue at the level of individual academics would be to include a number of potential explanatory variables for the sets of responses obtained from questionnaires. These could include:

- Prior experience of international collaborative work;

- Publication records for both academic journals and professional publications; - Visiting positions held at non-domestic universities. An examination of journal editors could also be valuable in giving a perspective on whether they are aware of how their journals are ranked and whether these have impacted submissions to their journal (e.g. number and quality). However, these are beyond the scope of the current study.

\section{Conclusion}

This study raises concerns regarding the increasing fixation on the use of in-house journal ranking guides and the potential impact on collaborative research in accounting. Our results show that the Chinese academics in our survey rely almost entirely on their own school's in-house journal ranking lists and appear to have limited knowledge about how journals are rated outside China. This is a recipe for potential conflict in regard to international research rather than the international engagement encouraged by bodies like AACSB, AMBA and EQUIS.

Nearly three quarters of respondents state that the use of ranking lists at their institution has caused problems when working with scholars from other universities because of differences in how their institutions rank journals. With regard to publication strategies, the majority of our respondents claim that the use of in-house ranking lists within Chinese universities is pushing academics away from professional 
journals (57\%) and also away from subject-specialist journals (72\%), mirroring

concerns raised previously by academic in Spain (Moya et al., 2014) and the

US/UK/Australia (Marriott et al., 2014), respectively. 
Appendix 1. The questionnaire (in English)

\section{Background}

1.1 Please give the name of your institution:

1.2 Please indicate $(\checkmark)$ total number of years service as an academic:

Less than 5 years

5 to 10 years

11 to 20 years

More than 20 years

1.3 Please indicate $(\checkmark$ ) your current position:

Professor

Associate professor/Reader/Senior lecturer

Assistant professor/Lecturer

Assistant professor/Lecturer

1.4 Please indicate $(\checkmark)$ if your school has any of the following accreditation:
AACSB
AMBA
EQUIS

1.5 Please indicate $(\checkmark)$ your top three research areas:

Management accounting

Accounting and capital markets

Accounting education

Accounting history

Auditing

Tax

Social and critical perspectives on accounting

Accounting for corporate governance

Environmental accounting

International accounting

Law and accounting

Financial reporting

Other

None (not research active) 
1.6 Please indicate $(\checkmark)$ if you have held any of these posts:

Head/Director of University

Dean of faculty or PVC

Head of school or department

Director of research for school or department

\section{Assessment of publication quality}

2.1 Please indicate $(\checkmark)$ if any of the following play a minor or major role within your school/department as part of the assessment of publication quality

\begin{tabular}{|c|c|c|c|}
\hline & Major & Minor & Not used \\
\hline Your school's own internal journal quality listing & & & \\
\hline The Association of Business Schools (ABS) listing & & & \\
\hline HKB - Hong Kong Baptist University School of Business & & & \\
\hline Australian Business Deans Council (ABDC) & & & \\
\hline Excellence in Research for Australia (ERA) & & & \\
\hline Financial Times (FT) list & & & \\
\hline ESSEC Business School Paris & & & \\
\hline VHB - Assoc. of Professors of Business in German speaking countries & & & \\
\hline $\begin{aligned} \text { WIE - WU Wien Journal Rating: Wirtschaftsuniversität Wien (Vienna } \\
\text { University of Economics and Business Administration) }\end{aligned}$ & & & \\
\hline $\begin{array}{l}\text { AERES - Agence d'évaluation de la recherche et de l'enseignement } \\
\text { Supérieur }\end{array}$ & & & \\
\hline EJL - Erasmus Research Institute of Management Journals Listing & & & \\
\hline 2 & & & \\
\hline
\end{tabular}

If you are not aware of any of these lists being used in your school, please go to Section 3.

2.2 In your experience, how much impact does the quality 'scores' in your institution's chosen lists have on an individual's career development? (please tick one)

The single most important factor

Moderate impact but teaching equally important

Very little impact - teaching is more important 
2.3 Do you think that it is more difficult for accounting researchers to gain highly ranked journal publications than researchers in general management areas? (please tick one)

Yes - it is more difficult for accounting researchers

About the same for both groups of researchers

$\mathrm{No}-$ it is easier for accounting researchers

2.4 Do you think that it is more difficult for management accounting researchers to gain highly ranked journal publications than researchers in other areas of accounting? (please tick one)

Yes - it is more difficult for management accounting researchers

About the same for both groups of researchers

No - it is easier for management accounting researchers

\section{The ABS Academic Journal Quality Guide}

3.1 Are you aware of the UK's Association of Business Schools (ABS) Academic Journal Quality Guide? (please tick one)

\begin{tabular}{|l|}
\hline $\begin{array}{l}\text { Yes - I have read the guide and I am aware of the ratings for those } \\
\text { journals in which I aim to publish }\end{array}$ \\
\hline $\begin{array}{l}\text { Yes - I have heard of the ABS guide but I have little knowledge of } \\
\text { the ratings it has suggested for those journals in which I aim to } \\
\text { publish }\end{array}$ \\
\hline No - I am not aware of the existence of the ABS guide \\
\hline
\end{tabular}

3.2 The ABS Journal Quality Guide rates journals on a scale of 1 to 4, where

4 = leading international journal;

$3=$ internationally excellent;

$2=$ internationally recognised;

1 = nationally recognised journal;

For example, journals such as Accounting and Business Research, AAAJ, Critical Perspectives on Accounting, and JBFA are given a score of ' 3 '. 
Please indicate how you would rate the following journals below in relation to the ' 3 ' rated journals mentioned above: higher (4), same (3) or lower (1 or 2). If you are unfamiliar with a journal please leave blank.

\begin{tabular}{|l|l|}
\hline & Your suggested rating $(4,3,2,1)$ \\
\hline Accounting Organizations and Society & \\
\hline Australian Accounting Review & \\
\hline Asia Pacific Journal of Accounting and Economics & \\
\hline Asian Review of Accounting & \\
\hline China Accounting and Finance Review & \\
\hline Contemporary Accounting Research & \\
\hline Journal of Accounting and Organizational Change & \\
\hline Journal of Accounting, Auditing and Finance & \\
\hline Journal of Contemporary Accounting and Economics & \\
\hline Journal of Contemporary Accounting and Economics & \\
\hline Journal of Management Accounting Research & \\
\hline Management Accounting Research & \\
\hline Pacific Accounting Review & \\
\hline Research in Accounting Regulation & \\
\hline
\end{tabular}

\section{The impact of journal ranking lists}

4.1 The use of ranking lists at my institution has sometimes forced me to reconsider sending papers to specialised academic journals that would be appropriate for my research because of their low ratings (please tick one)

I agree

I disagree

4.2 The use of ranking lists at my institution has sometimes caused problems when working with scholars from other universities because of differences in how their institutions rank journals. (please tick one)

I agree

I disagree

4.3 The use of ranking lists at my institution has sometimes forced me to reconsider sending papers to professional journals that would be appropriate for my research because of their low ratings (please tick one)

I agree

I disagree 


\section{Any other comments?}

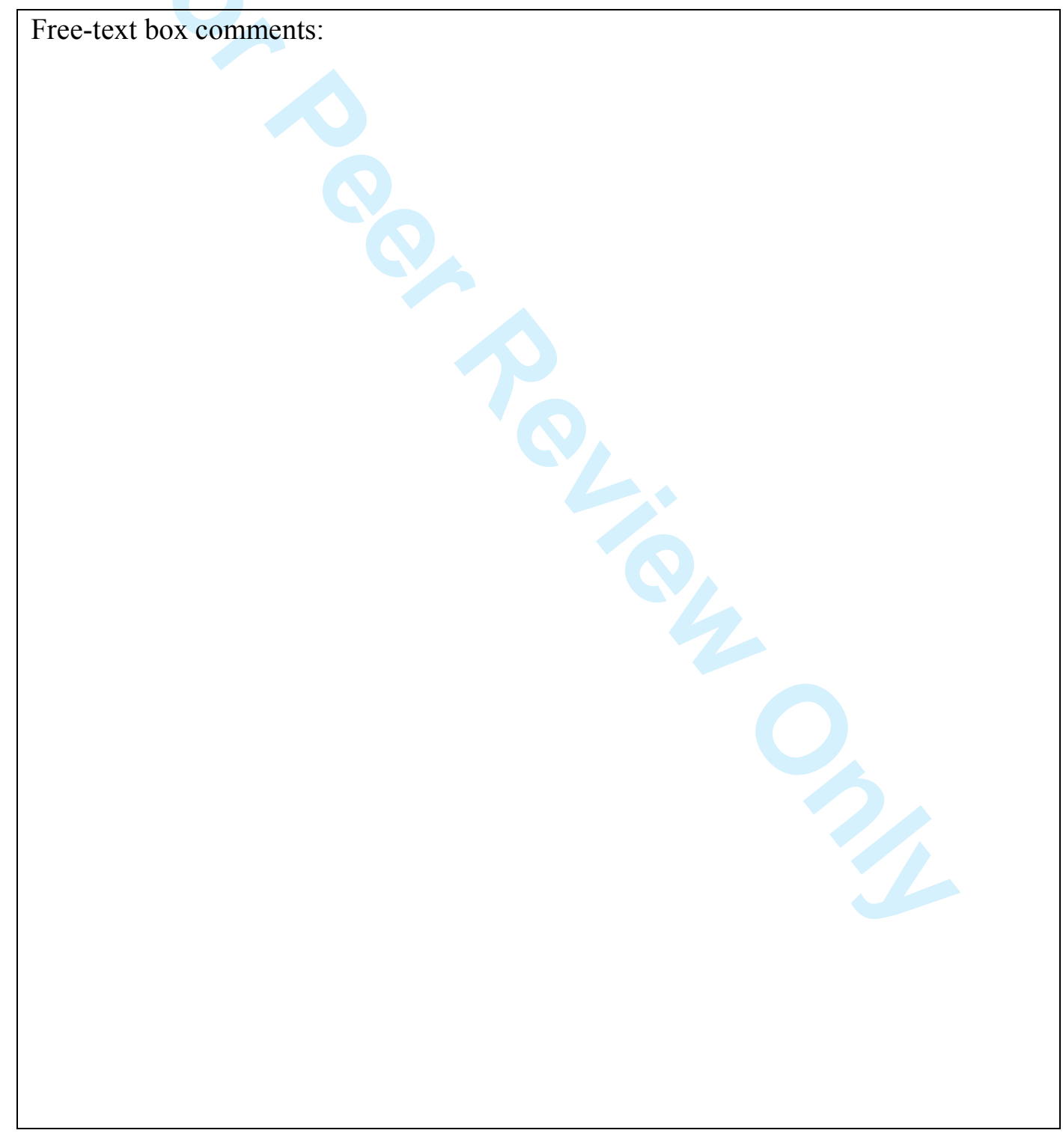

Thank you for your time and effort - your input is much appreciated.

4.4 The use of ranking lists at my institution has sometimes forced me to reconsider sending papers to newly launched academic journals because of their low ratings (please tick one)

I agree

I disagree

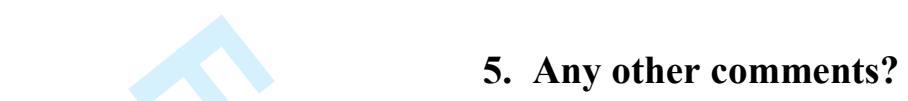


Appendix 2. Full set of responses (mean scores) for question 3.2 in the survey

\begin{tabular}{cc}
\hline Journal & All staff: \\
\hline Contemporary Accounting Research & 3.65 \\
Accounting Organizations and Society & 3.64 \\
Journal of Accounting, Auditing and Finance & 3.03 \\
Journal of Management Accounting Research & 3.00 \\
Management Accounting Research & 2.74 \\
Journal of Contemporary Accounting and Economics & 2.50 \\
Asia Pacific Journal of Accounting and Economics & 2.30 \\
Australian Accounting Review & 2.24 \\
China Accounting and Finance Review & 2.12 \\
Pacific Accounting Review & 2.09 \\
Research in Accounting Regulation & 2.05 \\
Journal of Accounting and Organizational Change & 1.95 \\
Asian Review of Accounting & 1.83
\end{tabular}

Quality scale: $4=$ leading international journal; $3=$ internationally excellent; $2=$ internationally recognised; 1 = nationally recognised journal 
Table 1. Characteristics of the respondents

\begin{tabular}{ccccc}
\hline Academic post & & & $\mathbf{N}$ & $\mathbf{\%}$ \\
\hline $\begin{array}{c}\text { Assistant professor/lecturer (Assist.) } \\
\text { Associate professor/senior lecturer (Assoc.) }\end{array}$ & & & 32 & 59.3 \\
Professor (PROF) & & & 17 & 31.5 \\
& & & 5 & 9.3 \\
\hline Institution & All staff & Assist. & Assoc. & PROF \\
& $\mathbf{( \% )}$ & $\mathbf{( \% )}$ & $\mathbf{( \% )}$ & $\mathbf{( \% )}$ \\
\hline 985 group (a subset of 211 universities) & 18.5 & 12.5 & 23.5 & 40.0 \\
211 universities & 59.3 & 59.4 & 52.9 & 80.0 \\
Non-211 universities & 40.7 & 40.6 & 47.1 & 20.0 \\
& & & & \\
\hline Experience (years) & All staff & Assist. & Assoc. & PROF \\
& $(\mathbf{\% )}$ & $\mathbf{( \% )}$ & $\mathbf{( \% )}$ & $\mathbf{( \% )}$ \\
\hline Less than 5 & 15.1 & 25.0 & 0.0 & 0.0 \\
5 to 10 & 64.2 & 75.0 & 64.7 & 0.0 \\
11 to 20 & 13.2 & 0.0 & 29.4 & 40.0 \\
More than 20 & 7.5 & 0.0 & 5.9 & 60.0
\end{tabular}

Note: China's ' 985 group' of 39 elite universities is a subset of the 116 universities which make up the research-intensive '211 group' of universities. 
Table 2. Respondents' main research interests

\begin{tabular}{ccccc}
\hline Research Areas: & All staff: & Assist. & Assoc. & PROF \\
\hline Accounting and Capital Markets & 74.1 & 78.1 & 76.5 & 40.0 \\
Accounting for corporate governance & 57.4 & 62.5 & 52.9 & 40.0 \\
Management accounting & 38.9 & 28.1 & 41.2 & 100.0 \\
Financial reporting & 38.9 & 46.9 & 23.5 & 40.0 \\
Auditing & 25.9 & 25.0 & 17.6 & 60.0 \\
Environmental accounting & 11.1 & 6.3 & 23.5 & 0.0 \\
Tax & 9.3 & 9.4 & 11.8 & 0.0 \\
Accounting education & 5.6 & 3.1 & 11.8 & 0.0 \\
International accounting & 5.6 & 6.3 & 5.9 & 0.0 \\
Non-accounting & 3.7 & 3.1 & 5.9 & 0.0 \\
Law and Accounting & 3.7 & 3.1 & 5.9 & 0.0 \\
Other accounting & 1.9 & 3.1 & 0.0 & 0.0 \\
Accounting history & 1.9 & 3.1 & 0.0 & 0.0 \\
Not research active & 0 & 0.0 & 0.0 & 0.0 \\
& 0 & 0.0 & 0.0 & 0.0
\end{tabular}

Note: Table shows the percentage of respondents who included a particular topic as one of their top-3 research areas. 
Table 3. Importance and difficulty of accounting research

\begin{tabular}{ccccc}
\hline Research issue: & All staff: & Assist. & Assoc. & PROF \\
\hline $\begin{array}{c}\text { Research is the single most important factor for } \\
\text { career development }\end{array}$ & 70.0 & 65.5 & 76.5 & 75.0 \\
$\begin{array}{c}\text { Gaining high ranked publications is more difficult } \\
\text { in accounting than in general management areas }\end{array}$ & 80.0 & 79.3 & 76.5 & 100.0 \\
$\begin{array}{c}\text { Gaining high ranked publications is more difficult } \\
\text { in management accounting than in other areas of } \\
\quad \text { accounting }\end{array}$ & 77.8 & 76.9 & 80.0 & 75.0
\end{tabular}


Table 4. Ranking lists used within respondents' schools to assess research

\begin{tabular}{ccccc}
\hline Major (Primary) Ranking Lists & $\begin{array}{c}\text { All staff } \\
(\mathbf{\%})\end{array}$ & $\begin{array}{c}\text { Assist. } \\
(\mathbf{\%})\end{array}$ & $\begin{array}{c}\text { Assoc. } \\
(\mathbf{\%})\end{array}$ & $\begin{array}{c}\text { PROF } \\
(\mathbf{\%})\end{array}$ \\
\hline Own School's list & 90.7 & 87.5 & 94.1 & 100.0 \\
HK(other) & 11.1 & 6.3 & 17.6 & 20.0 \\
FT45 & 5.6 & 0.0 & 11.8 & 20.0 \\
ABS & 3.7 & 0.0 & 5.9 & 20.0 \\
HKBU & 3.7 & 3.1 & 5.9 & 0.0 \\
& & & & \\
\hline Minor (Secondary) Ranking Lists & All staff & Assist. & Assoc. & PROF \\
& $\mathbf{( \% )}$ & $\mathbf{( \% )}$ & $\mathbf{( \% )}$ & $\mathbf{( \% )}$ \\
\hline ABS & 18.5 & 12.5 & 29.4 & 20.0 \\
FT45 & 9.3 & 12.5 & 5.9 & 0.0 \\
HKBU & 5.6 & 3.1 & 11.8 & 0.0 \\
EJL & 5.6 & 3.1 & 5.9 & 20.0 \\
ERA & 3.7 & 6.3 & 0.0 & 0.0
\end{tabular}

Note: Data in table show percentages of staff identifying each list as a major/minor source of journal quality ratings. Respondents can choose more than one in either category so column totals can exceed $100 \%$.

FT45 = Financial Times list of 45 leading business journals; ABS = Association of Business Schools Academic Journal Quality Guide (UK); HKBU = Hong Kong Baptist University list; HK(other) = lists from other Hong Kong based universities; EJL = Erasmus Research Institute of Management Journals Listing; ERA = Excellence in Research for Australia. 
Table 5. Respondents' knowledge of the UK's ABS guide

\begin{tabular}{ccccc}
\hline Knowledge of ABS guide & $\begin{array}{c}\text { All staff } \\
(\mathbf{\%})\end{array}$ & $\begin{array}{c}\text { Assist. } \\
(\mathbf{\%})\end{array}$ & $\begin{array}{c}\text { Assoc. } \\
(\mathbf{\%})\end{array}$ & $\begin{array}{c}\text { PROF } \\
(\mathbf{\%})\end{array}$ \\
\hline No knowledge of guide & 55.6 & 62.5 & 52.9 & 20.0 \\
Knowledge of ABS guide but not its ratings & 33.3 & 31.3 & 29.4 & 60.0 \\
Knowledge of ABS guide and its ratings & 11.1 & 6.3 & 17.6 & 20.0
\end{tabular}

Note: ABS Guide is the Association of Business Schools Academic Journal Quality Guide. 
Table 6. Respondents' suggested ratings for accounting journals

\begin{tabular}{|c|c|c|c|c|c|c|c|c|}
\hline 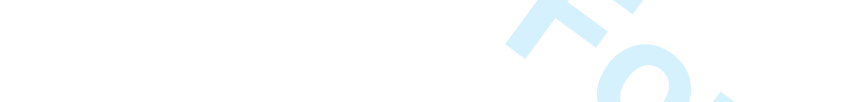 & \multicolumn{4}{|c|}{$\begin{array}{c}\text { Suggested Ratings from } \\
\text { Respondents }\end{array}$} & \multicolumn{4}{|c|}{ Ratings } \\
\hline 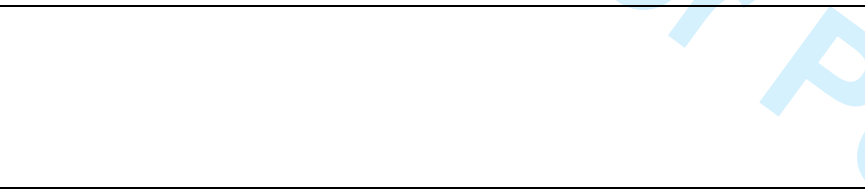 & All staff & Assist. & Assoc. & PROF & $\begin{array}{l}\text { ABS } \\
\text { (UK, } \\
\text { 2009) }\end{array}$ & $\begin{array}{l}\text { ABS } \\
\text { (UK, } \\
\text { 2010) }\end{array}$ & $\begin{array}{c}\text { Anonymous } \\
\text { Hong Kong } \\
\text { Chinese } \\
\text { university }\end{array}$ & $\begin{array}{c}\text { Shanghai U of } \\
\text { Finance \& } \\
\text { Economics } \\
(2009)\end{array}$ \\
\hline 'Top international' journals: & 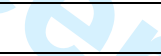 & & & & & & & \\
\hline Contemporary Accounting Research & 3.65 & 3.8 & 3.4 & 4.0 & '3’ & '3’ & 'A' & 'First tier' \\
\hline Accounting Organizations and Society & 3.64 & 3.6 & 3.7 & 4.0 & '4’ & '4' & 'B+' & 'Second tier' \\
\hline & & 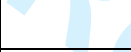 & 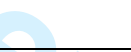 & & & & & \\
\hline Subject-specialist journals: & & & 8 & & & & & \\
\hline Journal of Management Accounting Research & 3.00 & 3.0 & 2.9 & 3.5 & '2' & '2’ & 'B+' & 'Second tier' \\
\hline Management Accounting Research & 2.74 & 2.8 & 2.6 & 3.0 & '3’ & '3’ & 'B' & 'Third tier' \\
\hline & & & & 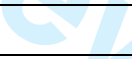 & & & & \\
\hline Asia Pacific focused journals: & & & & & & & & \\
\hline Journal of Contemporary Accounting and Economics & 2.50 & 2.6 & 2.3 & 3.0 & - & - & 'B' & - \\
\hline Asia Pacific Journal of Accounting and Economics & 2.30 & 2.4 & 2.1 & 3.0 & '1' & - & 'B' & - \\
\hline China Accounting and Finance Review & 2.12 & 2.1 & 2.2 & 1.0 & - & - & 'B-' & 'Third tier' \\
\hline Pacific Accounting Review & 2.09 & 2.0 & 2.1 & 3.0 & - & - & 'B-' & 'Third tier' \\
\hline
\end{tabular}

Note: Quality scales: ABS = Association of Business Schools (ratings: 4, 3, 2, 1); Anonymous leading Hong Kong Chinese university (ratings:

A, B+, B, B-); Shanghai University of Finance \& Economics (ratings: Top/First/Second/Third tier). 
Table 7. Problems experienced due to the existence of journal ratings

\begin{tabular}{|c|c|c|c|c|}
\hline Negative impact of journal lists & $\begin{array}{c}\text { All staff } \\
(\%)\end{array}$ & $\begin{array}{c}\text { Assist. } \\
(\%)\end{array}$ & $\begin{array}{c}\text { Assoc. } \\
(\%)\end{array}$ & $\begin{array}{c}\text { PROF } \\
(\%)\end{array}$ \\
\hline $\begin{array}{l}\text { The use of ranking lists at my institution has sometimes caused problems when working with scholars } \\
\text { from other universities because of differences in how their institutions rank journals }\end{array}$ & 73.1 & 71.9 & 73.3 & 80.0 \\
\hline $\begin{array}{c}\text { The use of ranking lists at my institution has sometimes forced me to reconsider sending papers to newly } \\
\text { launched academic journals because of their low ratings }\end{array}$ & 81.1 & 75.0 & 93.8 & 80.0 \\
\hline
\end{tabular}




\title{
References
}

\author{
AACSB, Association to Advance Collegiate Schools of Business: web-page \\ http://www.aacsb.edu/
}

Adler, N.J. and Harzing, A. (2009) When knowledge wins: transcending the sense and nonsense of academic rankings. Academy of Management Learning and Education, 8(1), pp.72-95.

\begin{abstract}
AMBA, Association of MBAs: web-page http://www.mbaworld.com/
Apostolou, B., Hassell, J.M., Rebele, J.E., and Watson, S.F. (2010). Accounting education literature review (2006-2009). Journal of Accounting Education, 28, pp.145-197.
\end{abstract}

Ashford, S. (2013) Having scholarly impact: the art of hitting academic home runs. Academy of Management Learning and Education, 12(4), pp.623-633.

\begin{abstract}
Au, K. (2007) Self-confidence does not come isolated from the environment. Asia Pacific Journal of Management, 24, pp.491-496.
\end{abstract}

Beattie, V. and Goodacre, A. (2006) A new method for ranking academic journals in accounting and finance. Accounting and Business Research, 36(2), pp.65-91. 
Beattie, V. and Goodacre, A. (2012) Publication records of accounting and finance faculty promoted to professor: evidence from the UK. Accounting and Business Research, 42(2), pp.197-231

Chan, K.C., Chan, K.C., Seow, G.S. and Tam, K. (2009) Ranking accounting journals using dissertation citation analysis: a research note. Accounting Organizations and Society, 34(6/7), pp.875-885.

Collet, F. and Vives, L. (2013) From pre-eminence to prominence: the fall of U.S. business schools and the rise of European and Asian business schools in the Financial Times Global MBA rankings. Academy of Management Learning and Education, 12(4), pp.540-563.

Currie, R.R. and Pandher, G. (2013) Management education journals' rank and tier by active scholars. Academy of Management Learning and Education, 12(2), pp.194-218

Dunbar, A.E. and Weber, D.P. (2014) What influences accounting research? a citations-based analysis. Issues in Accounting Education, 29(1), pp.1-60

EQUIS, European Quality Improvement System, web-pages http://www.efmd.org/index.php/accreditation-/equis/

Fleischman, R.K. and Schuele, K. (2009) Co-authorship in accounting history: advantages and pitfalls. Accounting, Business and Financial History, 19(3), pp.287303. 
Fogarty, T.J. and Jonas, G.A. (2013) Author characteristics for major accounting journals: differences among similarities 1989-2009. Issues in Accounting Education, 28(4), pp.731-757

Giacalone, R.A. (2009) Academic rankings in research institutions: a case of skewed mind-sets and professional amnesia. Academy of Management Learning and Education, 8(1), pp.122-126.

Glover, S.M., Prawitt, D.F., Summers, S.L. and Wood, D.A. (2012) Publication benchmarking data based on faculty promoted at the Top 75 U.S. accounting research institutions. Issues in Accounting Education, 27(3), pp.647-670

Grando, S.A. and Bernhard, J.D. (2003) First author, second author, et int., last author: a proposed citation system for biomedical papers. Science Editor, 26(4), pp.122-123.

Hafernik, J.J., Messerschmitt, D.S. and Vandrick, S. (1997) Collaborative research: why and how. Educational Researcher, 26(9), pp.31-35.

Hall, C. M. (2011) Publish or perish: bibliometric analysis, journal ranking and the assessment of research quality in tourism. Tourism Management 32, pp.16-27.

Harvey, C. and Morris, H. (2004) Classification of Academic Journals in the Field of Business and Management Studies (Bristol, UK: Bristol Business School). 
Harvey, C., Kelly, A., Morris, H., Rowlinson, M. (2010) Academic Journal Quality

Guide (4 ${ }^{\text {th }}$ edition). Association of Business Schools. http://www.the-abs.org.uk/

Helliar, C. (2010) Letter to Professor Huw Morris, Chair of the Association of

Business Schools. 19 April, 2010. British Accounting Association.

http://bafa.ac.uk/assets/files/BAA\%20-\%20Letter\%20to\%20ABS\%20-

\%20April\%202010.pdf

Hitt, M.A. and Greer, C.R. (2012) The value of research and its evaluation in business schools: killing the goose that laid the golden egg? Journal of Management Inquiry, 21(2), pp.236-240

Hoepner, A.G.F. and Unerman, J. (2012) Explicit and implicit subject bias in the ABS journal quality guide. Accounting Education: An International Journal, 21(1), pp.3-15

Holderness, D.K., Myers, N.M., Summers, S.L. and Wood, D.A. (2014) Accounting education research: ranking institutions and individual scholars. Issues in Accounting Education, 29(1), pp.87-115

Hussain, S. (2010) Accounting journals and the ABS quality ratings. British Accounting Review, 42(1), pp.1-16.

Hussain, S. (2011) Food for thought on the ABS academic journal quality guide. Accounting Education: an international journal, 20(6), pp.545-559. 
Hussain, S. (2012) Further food for thought on the ABS guide. Accounting Education: an international journal, 21(1), pp.17-22.

Hussain, S. (2015) Journal list fetishism and the 'sign of 4' in the ABS guide: a question of trust? Organization, 22(1), pp.119-138.

Jackling, B., Natoli, R., Nuryanah, S. and Ekanayake, D. (2013) Celebrating 20 years of publication of Accounting Education: an international journal: 1992-2011. Accounting Education: an international journal, 22(1), pp.18-43.

Katz, J.S and Martin, B.R. (1997) What is research collaboration? Research Policy, 26, pp.1-18.

Kelly, A., Morris, H., Rowlinson, M. and Harvey, C. (2009) Academic Journal Quality Guide ( $3^{\text {rd }}$ edition). Association of Business Schools. http://www.theabs.org.uk/

Laband, D.N. and Tollison, R.D. (2000) Intellectual collaboration. Journal of Political Economy, 108(3), pp.632-662.

Leung, K. (2007) The glory and tyranny of citation impact: an East Asian perspective. Academy of Management Journal, 50(3), pp.510-513. 
Malsch, B. and Tessier, S. (2015) Journal ranking effects on junior academics: identity fragmentation and politicization. Critical Perspectives on Accounting, 26, pp.84-98.

Marriott, N., Stoner, G., Fogarty, T. and Sangster, A. (2014) Publishing characteristics, geographic dispersion and research traditions of recent international accounting education research. British Accounting Review, 46, pp.264-280.

Melin, G. (2000) Pragmatism and self-organization: research collaboration on the individual level. Research Policy, 29, pp.31-40.

Mingers, J. and Willmott, H. (2013) Taylorizing business school research: On the 'one best way' performative effects of journal ranking lists. Human Relations, 66(8), pp.1051-1073

Moosa, I. (2011) The demise of the ARC journal ranking scheme: an ex post analysis of the accounting and finance journals. Accounting and Finance, 51, pp.809-836

Moya, S., Prior, D. and Rodriguez-Perez, G. (2014). Performance-based incentives and the behavior of accounting academics: responding to changes. Accounting Education: an international journal, http://dx.doi.org/10.1080/09639284.2014.947092 
Mudambi, R., Peng, M. and Weng, D. (2008) Research rankings of Asia Pacific business schools: global versus local knowledge strategies. Asia Pacific Journal of Management, 25, pp.171-188.

Nkomo, S.M. (2009) The seductive power of academic journal rankings: challenges of searching for the otherwise. Academy of Management Learning and Education, 8(1), pp.106-112.

Nedeva, M., Boden, R. and Nugroho, Y. (2012) Rank and file: managing individual performance in university research. Higher Education Policy, 25, pp.335-360.

Parker, M. (2014) University, Ltd: changing a business school. Organization, 21(2), pp.281-292

Rafols, I, Leydesdorff, L., O’Hare, A., Nightingale, P. and Stirling, A. (2012) How journal rankings can suppress interdisciplinary research: A comparison between Innovation Studies and Business \& Management. Research Policy, 41, pp.1262-82.

Rentz, K. (2009) The importance of "niche" journals to new business-communication academics — and to all of us. Journal of Business Communication, 46(3), pp.404-11.

Sangster, A. (2011) The ABS journal quality guide: a personal view. Accounting Education: an international journal, 20(6), pp.575-580. 
1

2

3

4

5

6

7

8

9

10

11

12

13

14

15

16

17

18

19

20

21

22

23

24

25

26

27

28

29

30

31

32

33

34

35

36

37

38

39

40

41

42

43

44

45

46

47

48

49

50

51

52

53

54

55

56

57

58

59

60

Taylor, J. (2011) The assessment of research quality in UK universities: peer review or metrics? British Journal of Management, 22, pp.202-217.

Tourish, D. (2011) Leading questions: journal rankings, academic freedom and performativity: what is, or should be, the future of Leadership? Leadership, 7, pp.367

Urbancic, F.R. (2009) Individual and institutional contributors to research in accounting education. Accounting Educators' Journal, 19, pp.21-44.

Willmott, H. (2011) Journal list fetishism and the perversion of scholarship: reactivity and the ABS list. Organization, 18(4), pp.429-442.

Zutshi, A., McDonald, G. and Kalejs, L. (2012) Challenges in collaborative writing: addressing authorship attribution, European Business Review, 24(1), pp.28-46. 